UDC 159.99

DOI: $10.26565 / 2410-1249-2020-13-02$

\title{
THE PRALOGICAL ESSENCE OF THE IMPLICIT ORDER
}

Tamara S. Yatsenko

Doctor of psychological sciences, Professor, Academician of the National Academy of the Pedagogical Sciences of Ukraine, The head of the chair of psychology, Bohdan Khmelnytsky national university of Cherkasy, Cherkasy, Ukraine E-mail: yacenkots@gmail.com, https://orcid.org/0000-0002-1996-66IX

\begin{abstract}
The article presents the research results of the archaic genesis of the implicit order. This term has been implemented into scientific use for more than a decade, however, it has so far been little described and lacked scientific substantiation. The article draws our attention to the fact that the implicit order of the psyche unites diametrically opposed tendencies that primarily correspond to the basic conflict "life $\leftrightarrow$ death". The sequence (order) of psychoanalytical analysis of art reproductions (selected for self-presentation) is set by a respondent, which proves the existence of blind hand skill. The implicit order proves the power of the basic law of pralogical thinking - involvement - which governs the pralogical thinking integrated with a modern person's reflexive, social and perceptive thinking. The article presents the results based on the stenographic material analysis of deep cognition of the psyche: audio and video of ASPC processes using thematic psycho-drawings "Fault tattoo" and "Own tattoo". The main argument of the pralogical essence of the implicit order is based on its main characteristic - neutrality to the discrepancy of its components which is exactly its pralogical essence. The ASPC participants arrange the visualized self-presenters ignoring (not noticing) their contradiction (conflict). The research gives an opportunity to state the connection of the "order" with the basic psyche conflict: "life" ↔ "death". The diagnostic-corrective process ASPC can actualize the self-preservation instinct by expanding the borders of subject's self-awareness with the increase of the behavior rationality, i.e. logical thinking efficiency.
\end{abstract}

KEYWORDS: active social-psychological cognition (ASPC), deep cognition, implicit order, tendency "to life" $\leftrightarrow$ "to death"; "implicit order"; logical thinking, pralogical (archaic, archetypal) thinking.

Introduction. The article for the first time describes the scientific generalization of long-term study of the fundamental nature of the psychic via the substantiation of the important structural component of the psyche - "the implicit order". This category represents a central chain in the "Psyche internal dynamics model" (Fig. 1), which expresses the unity and the interaction of two sphere of the psyche (conscious/unconscious) taking into account their functional asymmetry.

The latter stipulates the alogism (and thus discrepancy) under the law of involvement, which proves the existence of the implicit order of the psyche. This fact was studied by the ASPC participants selecting the self-representation means. The next step, offered by the psychologist, envisaged the arrangement of subjectified representations by their emotive value for the respondent. It is worth mentioning that all ASPC participants coped with the visualized selfrepresentations "arrangement" task, the essence of which was disclosed during the dialogue psychoanalysis carried out according to the images arrangement sequence determined by the respondent, by objectification of the hidden (invisible) interrelation between them.

Research method: active social-psychological cognition (hereinafter - ASPC) is represented in the literature from the point of view of its techniques and practical tool set development dynamics (Yatsenko, 2006, 2008, 2010). ASPC is based on diagnostic and corrective interaction of the psychologist and the respondent, provided the latter uses the visualized self-representations. The ASPC procedure in its entirety is subject to the basic mechanisms: "positive disintegration of the psyche and its secondary integration at the higher level of the psychological development".

The problem is in the binominal nature of the psyche organization system in its phenomenologic expression, which requires disclosure of the essence of the integration and distance interrelation between 
conscious and unconscious in their sequence, which gives grounds to speak about the existence of the psyche integrity. The inherence of the existence of two spheres of the psyche in the form of a unified system requires the disclosure of the nature of interrelations between the conscious and unconscious, which is supported by the category of the implicit order of the psyche (hereinafter - the order). The order represents the interests of both conscious and unconscious, integrating the force field of both spheres, which explains its overdetermination, i.e. specific autonomation from the both spheres. The introduction of this category (implicit order of the psyche) into the scientific use promotes the completeness of the psycho-dynamic paradigm from the point of view of the psyche structure which reflects the "Model of the internal dynamics of the psyche" (hereinafter - the Model, Fig. 1).

Purpose. To investigate the archaic (pralogical) nature of the implicit order of the psyche, which is explained by the neutrality of the order to the inconsistencies. Hypothesis: development of the psyche envisages the integration with the archaic heritage of the humanity in the midst of which Oedipus occupies the leading position, which affects the specific formation of pralogical thinking. The study was carried out with socially adaptive ASPC participants, mostly - future psychologists.

Results of the study. The results presented in an article are based on the analysis of verbatim material of deep cognition of the psyche using the ASPC method.

The main principles are inherence of the conscious and the unconscious combined with the duality of their relations. The duality of the human psyche structure (conscious/unconscious) is still the problem that has been underexplored. The following is obvious: neither of these spheres can functionally replace the other, and cannot be explored without the consideration of the "other side". The latter prompted the introduction of the "complementarity principle" (Yatsenko, 2017). The conscious and the unconscious are functionally asymmetric and at the same time these spheres of the psyche preserve the inherence within the unified system of the psyche integrity, outside which they stop existing. The conscious together with the unconscious fills the spontaneous action of the subject with content not due to the removal of contradictions, but through the process of their actualization, cognition and correction, which is what happens in ASPC groups. For a long time, the scientists have wondered why the psyche is characterized by the invisible contradiction, not represented in the consciousness, which is stabilized in the absorption of energy through the "freezing" process by camouflage and defense mechanisms.

A. Sheroziya point out that "the binominal system of relations can be the fundamental principle of the connection between the conscious and the unconscious" [Sheroziya, 1978, p. 355]. In the psychodynamic paradigm, the notion of the implicit order is comparable with the "binominal system", which outlines "the border" (horizon) of the conscious and the unconscious combination processes. The empirical material shows that the "implicit order" phenomenon is generated by nonexperience entities catalyzed by defenses in their contradictory trends - "to force" and "to weakness" (see "Model", arrows 3 and 4). The peculiarities of the "implicit order" lie in its archaic determination and pralogical unity of the contradictory components, which receive the opportunities for the research clarification only subject to the spontaneity of the subject's behaviour, the essence of which is revealed in the dialogue interaction in the system «Psychologist - Respondent» (hereinafter - "P $\leftrightarrow \mathrm{R}$ ").

Here we present the "Model of the internal dynamics of the psyche" (Fig. 1).

As the "implicit order" expresses the "averaging" chain between the spheres of the psyche (the conscious/ the unconscious), it is consistent with two directions "strength $\leftrightarrow$ weakness". The "implicit order" in the "model of the internal dynamics of the psyche" is shown in dots: the conscious ("visible dot") and the unconscious ("invisible" (space between dots)). It should be noted that the "implicit order" itself, in which the conscious and the unconscious are represented does not show the nature of the interrelation between the two spheres: the subjects ranks the reproductions, selected by them, (or 
prepared psychological drawings) according to the emotional significance that has long been the mystery for us. The subjectification of their own self-representation by the ASPC participants contributes to the objectivity of the psyche cognition in its entirety.
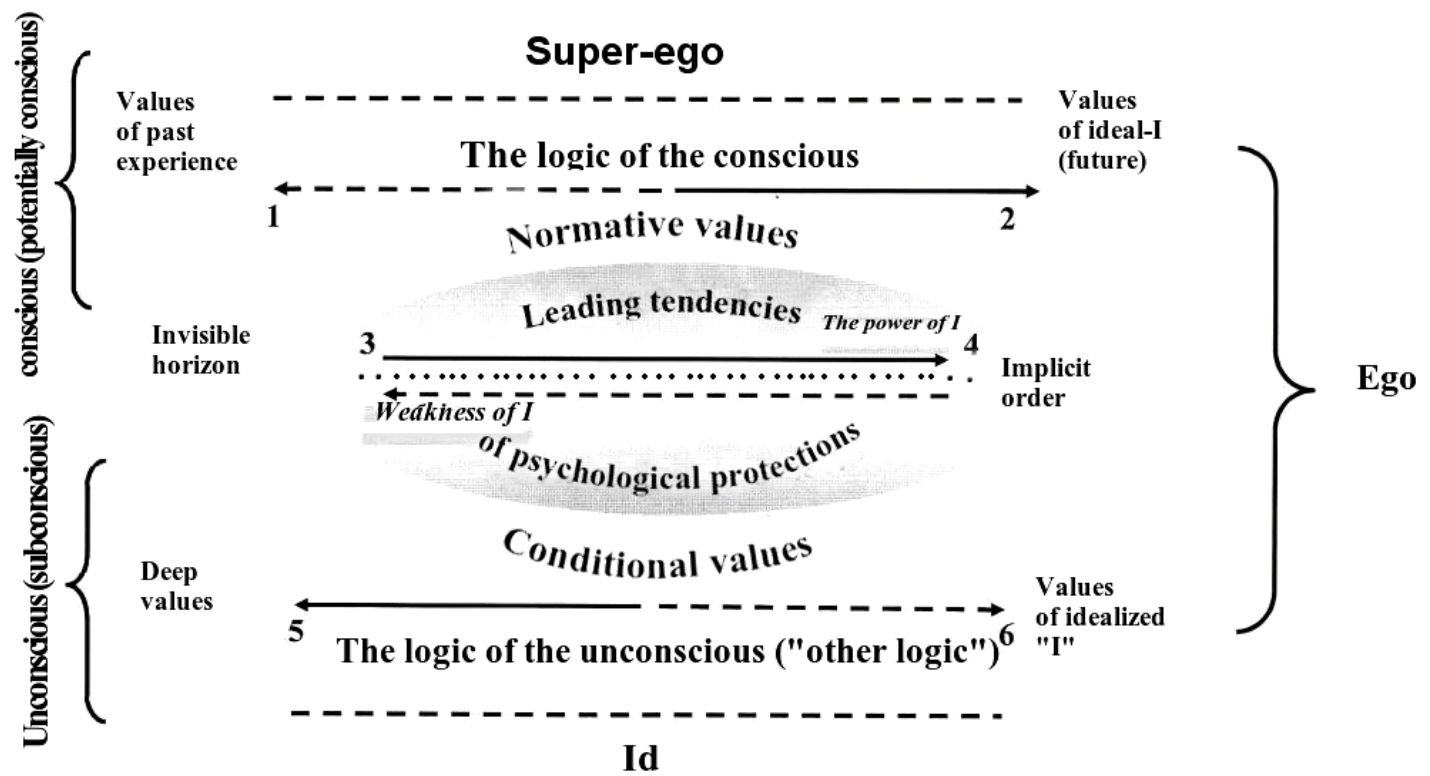

Fig. 1. Model of the internal dynamics of the psyche

The implicit order appears secondary and promotes spontaneous ranking (by emotional significance) of the visualized representations. As long as we have not clarified the problem of the archaisms (Yatsenko, 2019), the implicit order in ASPC was a practical catalyst for direct diagnostic and correction work rather than a scientific category. The revelation of the archaic motivational sources of the subject's spontaneous initiatives in combination with the "primary thinking" category (pralogical thinking) ${ }^{1}$ made it possible to find the pralogical substantiation of the "implicit order".

The foregoing allowed to understand the pralogical essence of the implicit (hidden, invisible) order, preserving the irrecognizability of the contradiction of the constituents, which does not interfere with the effectiveness of (but only contributes to) the ASPC process.

We can find the explanation in the fact that the pralogical thinking is neutral to contradictions, it sterilizes them, ignores, which is the characteristic feature of the implicit order of the psyche. This points to its archaic origin and the pralogical nature. The freedom (spontaneity) of the hand action has the prime role (when ranking the representations) in the objectification of the implicit order ${ }^{2}$. According to L. Levy-Bruhl, the "blind hand skill" exists archaically, which is subject to the basic law of the pralogical thinking - "involvement". The "competence of the hand initiative" of the respondent demonstrates the archaic nature of such skill, the context of which indicates the pralogical origin of the "implicit order".

Our forty years of research conclusively confirm the fact that "the psyche knows it all". This is what we rely on when complying with the conditions of the respondent's spontaneous activity.

That said, the important professional skill for a psychologist (in dialogue interaction with the respondent) is the ability to read meanings, hidden behind the specifics of the behavioural "pas". Based on the meanings (invisible to the respondent), the psychologist asks a question that contains the potential to control the diagnostic and correction
${ }^{1}$ L. Levy-Bruhl has been studying the problem of the pralogical thinking for thirty years [1].

\footnotetext{
${ }^{2}$ The researcher sets the paradigm: "rely on the will of the hand".
} 
process. The psychologist's question is his or her main instrument, which creates a problematic tension for a respondent who finds relaxation in the answer. This is how the deep cognition chain is built: in portions and multi levels; the psychologist's questions by themselves create the respondent's activity impulse. The amount of the auxiliary material selected by the respondent and the duration of the session allow to reach the unconscious constituent of the internal contradictions of the psyche.

It is safe to state that the ASPC process is based on the respondent's pralogical ability to determine the order of consideration of the visualized material. Every time a dialogue demonstrates that the sequence of images consideration optimizes and corresponds to the temporality of the diagnostic development of the subject's personal problem.

To sum up, we would like to note that the diagnostic and correction dialogue is based on the existing interrelations between the conscious and unconscious spheres (regardless of their functional asymmetry). The questions to the respondent are the major catalyst stimulus of the spontaneous impulses (energy that is displaced and fixed). It is the dialogue interaction that gives the research potency to the ASPC process, which explains the introduction of the zone - the "invisible horizon" (Hawking, 2014) and "implicit order" to the "Model", which contains in itself the symbol "Yin and Yang". The latter points to the need of dialogue interaction to achieve the diagnostic and correction result in the consideration sequence of art reproductions (or psychological drawings) selected by the respondent.

Speaking about personal attempts of the internal psyche cognition, C. Leclerc states that "this world is broken and illogical, sometimes masks itself, sometimes represents itself in the fog of its own imagination» (Leclerc, 1978, p. 262]. Thus, the architypical inclination of a human being to symbolization of the own psychological essence is evident. The image (as well as a symbol) represents the psychological contradiction and ambiguity that can gain symbolic integrity.

The world of the "displaced" experiences, which S. Freud connected to the stimulation of the symbolization of the unconscious activity, exists on the "other side of the consciousness". This is consistent with C. Leclerc's view, whom we have mentioned earlier, who believes that the unconscious is the "werewolf-conscious" (Leclerc, 1978, p. 357]. Inter alia, he states that "if this property of the unconscious psyche did not represent itself in the form of symbolic images of the conscious (long ago alienated by itself), we would not know anything about it" [ibid.].

The consciousness produces its attitude to such creations of the psyche through mental attitude of the person to themselves and all that surrounds them. The latter is used in the psychodynamic paradigm to construct the dialogue interaction in the "P $\leftrightarrow \mathrm{R}$ " system. The consciousness depends on the peripheral defense system of the psyche, which masks its contradictory essence, and we see it as the subordination of the defense system to the pralogical tendencies. The conscious, due to symbolic images (desires, art, religion, dreams, "day-dreams"), invisibly to itself causes the manifestations of the secret desires, while trying to hide their meanings by resistance to any penetration into the latent aspects of the psyche. For example, when under hypnosis, a person does something unconsciously, but then is able to rationalize why they did it. The person usually gives a defensive response without noticing the deviations from the reality.

In psychodynamic paradigm, which we have been developing for over forty years, the bank of empirical data proves that the adequate cognition of the psyche requires the introduction of the complementarity principle, which is fundamental, starting "postulate", a precondition for revealing the essence of the psyche in its entirety (Yatsenko, 2017). The complementarity principle was in its time introduced in the quantum physics by Niels Bohr. Taking into account the subjectivity of the psyche we take this principle in two capacities: "principle of the inherence of the conscious and unconscious spheres" and "principle from the other" (hereinafter - "from the other"). The latter is outlined by a number of postulates which the psychologist must respect during the the diagnostic and corrective interaction 
with the respondent, which we have presented in the corresponding article (Yatsenko, 2017).

The language of the conscious creates the hidden dialectics of the relations, established by the "different logic", in which the categories of time, space, sex and causality function differently, than in the sphere of the conscious (at which S. Freud has pointed). An important part in this aspect is occupied by the mnemonic traces, created by displacement, synthesized with archaisms, and are the embodiment of the generations socialization drama. The psyche uses a set of world images (animate and inanimate nature) for this process, which can by means of the symbolization mechanisms (concentration, shifting, hint, spatial location dynamics, colour etc.) transmit the information equivalents in the "other body", in other visual variations. C. Leclerc writes that "it would be naive to localize these imprints of the human history only in the brain, they are inscribed everywhere in the world" (Leclerc, 1978, p. 264]. It is impossible to create a catalogue (or a hierarchy), because they are archaically motivated and fused with the basic forms of defense, the interests of which are expressed by the archetype nature of the symbols. It is important to take into account that the basic forms of defense, associated with the "wisdom of generations" cannot be announced independently outside the situational defenses. The spontaneous activity of the subject involves the horizontal (basic) and vertical (situational defenses) intersection. Thus, the expression of the archaic inheritance is always integrated and agreed with the individualized emotional content of the subject's psyche.

We have already mentioned that the dialogue ("P $\leftrightarrow \mathrm{R}$ ") is of ultimate importance for the problem of reaching the individual uniqueness of the psyche. Under such circumstances, the words are "instruments of labor" for the psychologist whose effectiveness depends on the ability to read meanings. It the meaning that combines in itself the visible and invisible, emotive and rational. The words of the psychologist, without the diagnostic precision, will be the dead sounds.

The logic of the unconscious sphere is paradoxical (beyond time, space, sex etc.).
However, the problem of its cognition through the language of the conscious is solved in it. Each of the "conscious / unconscious" logic systems is in contact with one another in some way, although it can never be reduced to any of them. Their contact is even harder to "catch" than the contact of the sound waves in space. And this contact (involvement) is the essence of the existence of the common uniting chain, which confirms the interaction of the conscious and the unconscious, exactly what the implicit order is, which expresses the archaic mindset and subordination to the involvement law!

The sequence of expression of the implicit order and the need for its consideration by the psychologist during work with the respondent is explained by the fact that it [the order] has formed by itself (beyond the control of the consciousness), and therefore promotes the holistic objectification of the psyche in the contemplation plane. The order cannot be either erased or modified or deformed, as it is not written in advance and does not belong to any substrate; it is determined by the cross-section, intersection, interference of power networks, the background of which is represented by certain integration meta-meanings, related to both the conscious and the unconscious irrespective of the experience. The "order", as we have already mentioned, is related to the fact established in the psychodynamic paradigm that "the psyche knows everything". Thus, the psychic is not reducible to the conscious. The "order" in its archaic predetermined nature has energy potential, the use of which is subject to the dialogue interaction, which activates both spheres of the psyche on the basis of the probabilistic forecasting. It is important, because the "order" exists "above" both spheres of the psyche and at the same time absorbs their essence, which is indirectly expressed via a representation.

We would like to emphasize that the practice of in-depth cognition of the psyche shows that the "order" is immanently (that is beyond the subject's control) inherent to the psyche of every person.

Hypothesis: the language of the unconscious is expressed not in the images, symbols, but rather in 
their meanings, which are the equivalent interrelations between the subjectified representations. It is the number of pictures that allows to determine the differences in the direction of the psychic activity vectors at the level of the conscious and the unconscious through longitudinal analysis.

The paradox is that the implicit order does not solve the problem of the psyche integrity, it only expresses the problem indirectly through the involvement of the visualized representations. That is why we observe the semantic alogism, for example, one drawing "to health" (Fig. 2), and the other (Fig. 3) "with a sorry sight". The insensitivity to inconsistency proves the pralogical essence of the "order", its predetermination. Here is an example.

\section{We present a small fragment a long psychoanalytical work with the female student of the psychological department of Bohdan Khmelnytsky Cherkasy National University (2018) ${ }^{3}$.}

N.: I chose Fig. 2 first, making accent on the "head" (at the top of the statue), i.e. development of the intellect - everything starts from the head (points to the light near the statue, Fig. 2.

P.: So, you focus on your own mind?

N.: Maybe, though this requires to weaken the "darkness" of the soul to have the light mind.

P.: This Fig. 2 can be considered as self-birth? Do you accept such hypothesis of self-birth now?

N.: I rather do, because I feel this inner need.

P.: So, self-birth for you is intellectual rebirth through rethinking your life experience to understand, how you harm yourself?

N.: Yes, without a doubt, because this is what keeps me in some internal "unwise" statics, emptiness, something like a stop in the darkness of my own soul.

P.: You are good at self-reflection, and there is hope for the release from the "darkness" you are talking about. Biologically we cannot be born twice, but we can help ourselves in rethinking of the situations we had and understand their consequences. Let's move to the next picture from

\footnotetext{
${ }^{3}$ The full text of the verbatim with respondent N. is presented in the book [16].
}

the previous session (Fig. 3). What have you learned from this picture, what did it help you to understand?

N.: Most of all - the role of the "skeleton" (on the right) in my life.

P.: This skeleton is not just a mere symbol, is it a part of you?

N.: Yes, of course, this is my self-awareness, this alienation of the own flesh (body), the femininity in myself, life aspect. The skeleton has no sex. Now I understood why I ignore this girl in picture 3. It is defense - I have no sex, it is easier for me, as if my body is absent.

P.: It is a real mystery for me that you alienate this sensual, beautiful girl.

N.: I do not pay any attention to her - she does not exist for me. And now, too, I cannot look at her seductive look, it's terrible.

P.: This is what strikes me. You are young, beautiful, and you have a lifetime ahead of you, but you ignore all of this? You could rather relate yourself to a girl than a skeleton, because you are young, tender and pretty. Perhaps you can address the "girl" and the "skeleton" with some text.

N.: No, I can't, it's too hard, especially to talk to the girl... The skeleton is the residue of my sufferings in my soul.

P.: So, you alienate your beauty, harmony, which is presented to the outside? As well as your femininity, attractiveness?

N.: Yes, I do alienate them. And I have a feeling that changing anything is beyond my strength!

P.: Then, obviously, the boys have trouble with you, they face resistance?

N.: Computer is OK with me.

P.: You kill intimate relationships or replace them with a computer? Or you refer the boys to the "mechanics" category?

N.: I just do not communicate with them. I feel better off myself, calmer, more comfortable. I do not bother other people, and I'd want to have the same attitude from them.

P.: But they may be showing some interest in you, because you are a feminine, pretty girl?

N.: "Good-bye!" - the ready shield for all occasions! If I am not interested or I don't like something - that's it! There's no other option. 
P.: But you saying, that you do not like the person at the first glance. You are not ready to get acquainted, to know the person better. I can understand that with the boys, but why do you alienate this girl in Figure 3?

N.: I don't know what to say... I guess it's because I alienate myself, I do not accept my own feminine aspect. It seems to me, that I will have only problems, I had that when I was a child. It was stepfather's violence. That is why, I would tell the girl: dress up.

$$
* * *
$$

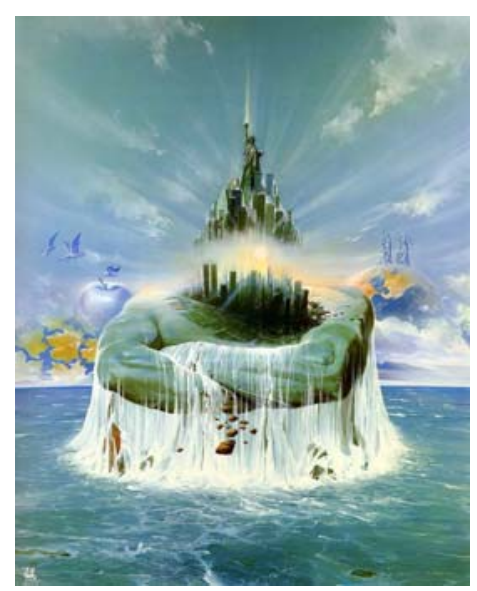

Fig. 2. Wojtek Siudmak - The Strongest

The respondent $\mathrm{N}$. chose more than twenty pictures (which she arranged by importance). We present only two of them, and within a short period of time they helped to objectify a huge layer of N.'s hidden experience (drama of violence). This fragment of the psychoanalysis shows that the unconscious can be objectified by context and indirectly, which is greatly supported by visualized self-presentation. Given the unconscious predetermination of the implicit order, it always preserves the energy potency, which stipulates the motivation nature of the respondent's spontaneous behaviour in the psychoanalytical interaction with the psychologist. Conclusion: in the dialogue interaction of the psychologist with the respondent the implicit order establishes the sequence of the psychologist and respondent dialogue interaction process temporality. The diagnostics and correction dialogue is subject to the following principles: non-mergence of " $\mathrm{P} \leftrightarrow \mathrm{R}$ " positions and their integrity.

The foregoing explains the significant difference between the process of deep cognition and the specifics of the academic experimental study in which the "order" of the study procedure is pre-

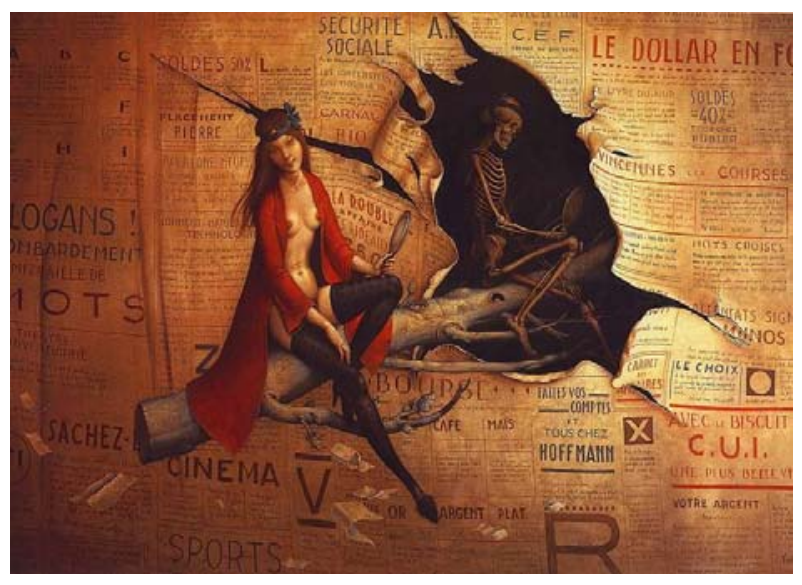

Fig. 3. C. Verlinde-La Dechirure

determined and planned by the researcher. The lead (psychologist) of the in-depth cognition is a "slave" of the "following the ..." process in the wake of the respondent's internal activity continuum that defines the content of the " $\mathrm{P} \leftrightarrow \mathrm{R}$ " interaction. The psychologist's questions are based on the probabilistic forecasting, that is why the psychocorrection dialogue is different from the dialogue in its usual sense (as the exchange of information). In ASPC the "information" needs to be obtained in the process of interaction between a psychologist and a respondent, which is based on the probabilistic forecasting, including the interpretation of the accumulated behavioral material. The psychologist only sets the prerequisites for the objectification of the latent factors to the information field of the in-depth cognition. The dynamics of the dialogue interaction procedure in general is based on the cognition of meaning parameters, the "implicit order" to a large extent performs the organizational role.

Summing up, we would like to note that in indepth cognition, which envisages following the spontaneous activity of the respondent, the determining role still belongs to the psychologist, 
their ability to perform the procedural diagnostics (by portions and at many levels), which is inseparably connected to the correction.

The dialogue cooperation of the psychologist with the respondent facilitates the accumulation of the behavioural material, semantically potent in the objectification of the hidden conceptual parameters of the psyche, understanding of which increases the consciousness of the subject. Under such conditions the dialogues become the catalyst of the expansion of the subject's self-awareness, which is the necessary condition for them to reconstruct the erroneous positions. Taking into account the functional incompatibility of the two spheres, the implicit order integrates the power fields: "conscious / unconscious". Therefore, the deployment of the individually unique initiative of the respondent offers the prospect of learning the alogism and irrationality in spontaneous selfpresentation of the subject, subject to cognition, which extends the scope of self-awareness.

Temporality (spread in time) of the respondent's behavior depends on the diagnostic feasibility of the psychologist's questions that should be understood by the respondent, the criterion of such understanding being the energy boost of their behavior. Figuratively the detection of the implicit order can be compared to the calendar, the pages of which are strictly organized and yet are filled with individualized diametrically opposite meaning. The semantic parameters of the implicit order are unique for each individual.

The words of C. Leclerc come to mind: "only in the field of psychoanalytical experience it became possible to determine the existence of the "different logic", logic of the unconscious. And those who profess for strict scientific research of the essence of the human psyche, must pay the utmost attention to this "different logic" (Leclerc, 1978, p. 269]. This "different logic" can not be given to the psychologist separately, as well as the implicit order. The "different logic" can be objectified by a longitudinal analysis of the respondent's spontaneous behaviour, the orientation on the identification of invariant characteristics in it.
The psychodynamic paradigm sets the direction of the in-depth cognition on the "invisible horizon" line (i.e. the neutral zone between the conscious and the unconscious), which is specified in the implicit order.

The latter stipulates our attention to the implicit order, which latently and masterly assimilates and objectifies the "worries" of both spheres. The psychodynamic paradigm takes into the fact that the unconscious is programmed by the archaically exhaustless "over-determination", which points to the need of the psychologist's orientation on the fact that "the psyche knows everything, not only the conscious".

It is important to understand that any act of spontaneous behavior occurs at the intersection of "horizontal" and "vertical", which is the explanation to the interaction of defenses: basic (horizontal) and peripheral (vertical). The secretness of the implicit order I is ensured by its [order's] freedom from the influence of the "civilization logic", which in fact keeps I in informational captivity. The implicit order is et latently according to the laws of the pralogical (archaic) thinking, which explains its complete neutrality to the contradictory nature of its "constituents". The latter can point to the fact that the involvement law, which is central in the formation of the primitive men psyche, is unnoticeable for the psyche in the opposition of two logics: the logic of the conscious and the "different logic" (the unconscious). The reason for this may be the fact that the pralogical predetermination in the psyche belongs to the basic form of defense, which have never been represented in the subject's consciousness. Basic protection is the formation beyond experience that relates to the situational (peripheral) defenses only at the time of the external manifestation. They coexist on mutually beneficial terms: basic defenses have a preset archaic energy potential, and the peripheral pursue the purpose of adaptation to modern understandable forms of self-presentation. That is why it is a good idea for every person to go through the course of the in-depth cognition, to rely on the objectivity of the self-presentation 
forms and determine the problem of existence of the internal conflict, which while being invisible (masked), absorbs the energy like the "black hole". S. Hawking said that the motto of those falling in the Black hole is "you think it wrong" (Hawking, 2014, p. 112]. Thus, he pointed out that an important proactive aspect of personal problems is their cognitive rethinking (reconstruction) and resolving the contradictory trends in the psyche.

In other words, the in-depth correction process means finding the errors in the cognitive construct of self-identity and self-awareness of the person, which determines the understanding of the oneself ad other people. To avoid the situation when not only the "conscious is not the master in its own house" (S. Freud), but the thinking of the modern person can turn out not being the master of its own self-perception, as well the perception of other people. And the person has to pay for this with their social success, career, health, because it stipulates the tendency to "psychological death" (Yatsenko, 2008), self-deprivation (Yatsenko, 2016) or aggression (Yatsenko, 2010). The feeling of a loser, being pathetic and unneeded can accompany the above.

Summary. The in-depth psychocorrection can give people the joy of self-discovery, which reduces emotional tension. Attendance of the ASPC group allows to gain a sense of inner peace, harmony and homeostasis. The in-depth self-analysis during ASPC promotes the social and perceptual intelligence; a person step by step, in portions and at many levels discovers their own personal potential, energy of which creates the prospects of selffulfillment.

The significance of the article is not only the novelty (the problem of the pralogical (archaic) nature of the implicit (hidden, invisible) order is described for the first time), but also in the existing predetermined nature of the hidden motivation dynamics.

It is important to understand that every person is the closest person to themselves and that is why it is important to learn to give joy to yourself (through self-awareness) by actions and throughout life! In general, every person should be necessary for themselves, and then others will be in the sphere of the attention. The foregoing problems at the same time determine the perspective for further research.

\section{REFERENCES}

Levy-Bruhl, L. (1930). Primitive Mentality. Oxford: Clarendon Press.

Leclerc, C. (1978). The Unconscious: Other Logic. Tbilisi: Metsniereba.

Shevchenko, L.I. (Ed.). (2008). New Dictionary of Foreign Words: about 40000 words and phrases. Kyiv: ARIY.

Prigozhyn, I. (1986). Order from the Chaos: New Dialogue of a Man with Nature. Arshynov V.I., Klimontovich Yu.L., Sachkov Yu.V. (Ed.). Moscow: Progress.

Hawking, S. (2014). The Universe. Three Books about Space and Time. St. Petersburg; Amfora, Petroglif.

Galperin P.Ya., Zhdan, A.N. (Ed.). (1980). Anthology of History of Psychology. Moscow: Publishing House of the Moscow University.

Sheroziya, A.Ye. (1978). Consciousness, Unconscious, the Psychic and the System of the Fundamental Relations of the Personality: Prerequisites of the Common Theory / Tbilisi: Metsniereba.

Yatsenko, T.S. (2006). Fundamentals of In-Depth Psychocorrection: Phenomenology, Theory and Practice: Acad. guide. Kyiv: Vyshcha shkola.

Yatsenko, T.S. Gluzman, O.V., Kalashnik, I.V. (2008). Depth Psychology: Diagnosis and Correction of the Tendency to Psychological Death. Acad. guide. Yalta: RVV KSU.

Yatsenko, T.S., (Ed.). (2010). Aggression: Psychological Theory and Phenomenology. Kyiv: Vyshcha shkola.

Yatsenko, T.S. (2015). Dynamics of the Depth Psychocorrection Development: Theory and Practice. Denpropetrovsk: Innovatsiya.

Yatsenko, T.S., Gluzman, A.V. (2015). Methodology of the Depth-Correction Preparation of the Psychologist. Denpropetrovsk: Innovatsiya.

Yatsenko, T.S. Bondar, V.I. (2016). In-Depth Cognition of the Self-Deprivation of the Future Psychologist's Psyche. Kyiv: National Pedagogical Dragomanov University.

Yatsenko, T.S. (2017). Categories of "Complementarity Principle" and "Implicit Order" in In-Depth Cognition of the Psyche. Personality Psychology. 1(8). 15-23.

Yatsenko, T.S. (2018). The Relationship of Conscious and Unconscious Psychodynamic Approach. In Fundamental and applied researches in practice of leading scientific schools. 26(2). pp. 335-353. Kyiv.

Yatsenko, T.S., Bondar, V., Halushko, L., Kaminska, A., Pedchenko, O. (2018). Psychoanalysis of the Art Reproductions in the Preparation of Psychologists: Academic Guide. Dnipro-Kyiv: Innovatsiya.

Yatsenko T.S. (2019). The Archaic Inheritance of the Psyche: Psychoanalysis of the Problem Phenomenology.Dnipro: Innovatsiya. 


\section{ІМПЛІЦИТНИЙ ПОРЯДОК У ЙОГО ПРАЛОГІЧНІЙ СУТНОСТІ}

T. С. Яценко

Доктор психологічних наук, професор, академік НАПН України, завідувач кафедри психології, глибинної корекції та реабілітації, Черкаський начіональний університет імені Богдана Хмельницького, м. Черкаси, Украӥна У статті вперше презентується результати дослідження архаїчного генезису імпліцитного порядку. Цей термін введено нами у науковий обіг уже понад десятиріччя, проте він залишався досі малорозкритим та недостатньо науково обгрунтованим. Зміст статті звертає увагу на те, що імпліцитний порядок психіки єднає діаметрально протилежні тенденції психіки, які відповідають базальному конфлікту «життя ↔ смерть». Послідовність (порядок) психоаналітичного розгляду репродукцій художніх полотен (обраних суб’єктом для самопрезентації) задається самим респондентом, що засвідчує наявність «сліпої навички» руки. Імпліцитний порядок є доказом дієвості провідного закону пралогічного мислення - «співпричетність», якому підкорене пралогічне мислення, що інтегрується з рефлексивним, соціально-перцептивним мисленням сучасної людини. Результати статті вибудувані на аналізі стенографічного матеріалу глибинного пізнання психіки: аудіо- та відеозаписах процесу АСПП із використанням тематичних психомалюнків «Тату вини» та «Власного тату». Основний аргумент пралогічності імпліцитного порядку грунтується на провідній характеристиці - нейтральність до суперечливості його складових, у чому й криється його пралогічна сутність. Візуалізовані самопрезентанти впорядковуються учасниками АСПП ігноруючи (не помічаючи) їхню суперечливість (конфліктність). Дослідження дає змогу констатувати зв'язок «порядку» $з$ базальним конфліктом психіки: «життя» « «смерть». Діагностико-корекційний процес АСПП спроможний актуалізувати інстинкт самозбереження шляхом розширення у психіці суб'єкта меж самоусвідомлення 3 посиленням раціональності поведінки, тобто дієвості логічного мислення.

КЛЮЧОВІ СЛОВА: активне соціально-психологічне пізнання (АСПП); глибинне пізнання; тенденція «до життя» ↔ «до смерті»; «імпліцитний порядок»; логічне мислення; пралогічне мислення.

\section{ИМПЛИЦИТНЫЙ ПОРЯДОК В ЕГО ПРАЛОГИЧЕСКОЙ СУЩНОСТИ}

Т. С. Яценко

Доктор психологических наук, профессор, академик НАПН Украины, заведующая кафедрой психологии, глубинной коррекции и реабилитации, Черкасский национальный университет шимени Богдана Хмельницкого, г. Черкассы, Украина. В статье впервые представлены результаты исследования архаического генезиса имплицитного порядка. Этот термин введен нами в научный обиход уже более десяти лет, однако он оставался до сих пор научно малораскрытым. Содержание статьи обращает внимание на то, что имплицитный порядок психики объединяет диаметрально противоположные тенденции, прежде всего, те, что соответствуют базальному конфликту «жизнь» « «смерть». Последовательность (порядок) психоаналитического рассмотрения репродукций художественных полотен (подобранных субъектом для самопрезентации) задается респондентом, что свидетельствует о наличии у него пралогического навыка («слепой навык» руки). Имплицитный порядок является доказательством действенности закона «сопричастности», которому подчинено пралогическое мышление, интегрирующееся с рефлексивными формами мышления современного человека. Результаты статьи базируются на анализе стенографического материала глубинного познания психики: аудио- и видеозаписей процесса АСПП с использованием тематических психорисунков «Тату вины» и «Собственное тату». Основной аргумент пралогичности имплицитного порядка основывается на ведущей характеристике - нейтральность к противоречивости его составляющих. Визуализированые самопрезентанты упорядочиваются участником АСПП игнорируя (не замечая) их противоречивости (конфликтности). Исследование позволяет констатировать связь имплицитного порядка с базальным конфликтом психики: «жизнь» $\leftrightarrow$ «смерть». Диагностико-коррекционный процесс АСПП способен актуализировать инстинкт самосохранения путем расширения у субъекта границ самоосознания, что предполагает усиление рациональности поведения, т. е. действенность логического мышления.

КЛЮЧЕВЫЕ СЛОВА: активное социально-психологическое познание (АСПП); глубинное познание; тенденция «к жизни» « «К смерти»; «имплицитный порядок»; логическое мышление; пралогическое мышление. 